\title{
CAPITAL GRANTS AND REGIONAL PUBLIC INVESTMENT IN SPAIN: FUNGIBILITY OF AID OR CROWDING IN EFFECT?
}

Key words:

Capital grants, public investment, crowding-in effect, crowding-out effect, regional policy, Spain, fiscal federalism.

Abstract:

Capital grants to subcentral governments aim to increase their investment. However, they may try to allocate additional resources to cut saving or deficit, reducing self-financed investment and generating a crowing-out effect on regional public investment. Using data for Spanish Autonomous Communities (ACs) during 1984-1999, the effect of capital transfers on regional public capital spending, saving, and deficit is estimated. Econometric results point out that capital grants are not relevant to explain the dynamics of saving, but they are negative and significant in deficit regressions once institutional differences among ACs are controlled for. Besides, while the estimated short-run multiplier of grants on capital spending is around 0.4 the long-run multiplier would be close to 1 .

In conclusion, although grants have been partially used to reduce deficit in the short run, the existence of significant crowding-out or crowding-in effects of grants on self-financed investment in the long run may be discarded.

\section{SANTIAGO LAGO-PEÑAS}

Departamento de Economía Aplicada

Facultade de Empresariais

Campus de Ourense

Universidade de Vigo

32004 Ourense

SPAIN

E-mail: slagop@uvigo.es 


\section{INTRODUCTION}

The effects of grants on fiscal choices are analysed in two fields of economic research. Fiscal federalism investigates the consequences of different kind of grants on expenditures made by subcentral governments. This topic is included in classical handbooks as Oates (1972), King (1984) and Wildasin (1986) and it has been the object of a huge number of theoretical and empirical studies ${ }^{1}$. Besides, specialists on economic development are concerned with the fiscal effects of international aid -grants and loans- in recipient countries. Papers by Heller (1975), Gang and Khan (1991), Pack and Rothenberg (1990, 1993), Khan and Hoshimo (1992), and Otim (1996) are good examples. Both approaches seem useful to study regional policy EU style, a sort of financial relations placed between intergovernmental relations and international aid, based on grants and built on co-ordination among several levels of government.

The aim of this paper is the analysis of the effects of capital grants on fiscal choices made by the Spanish regional governments during the period 1984-1999. In particular, I am interested in the question of fungibility of grants-in-aid and the relevance of crowding-out or crowding-in effects on self-financed investment. Section two presents the main institutional features of fiscal federalism and regional policy in Spain. Section three is devoted to present a simple model of choices on public spending composition and data used. Econometric results are discussed in section four. Section five concludes.

\footnotetext{
${ }^{1}$ For the specific purposes of this paper, see Zampelli (1986), Meyers (1987), Grossman (1989), Islam and Choudhury (1990), Zou (1994), Chernick (1998), Gamkhar (2002), and Knight (2002).
} 


\section{FISCAL FEDERALISM AND REGIONAL POLICY IN SPAIN: A BRIEF OVERVIEW}

Regional policy in Spain is based on capital transfers to regional governments ${ }^{2}$ from the Central government and the EU. Certainly, some grants from the EU cover current spending; central government makes other kind of efforts to correct differences in regional levels of development, like tax incentives and direct investment ${ }^{3}$; and not all capital grants obey to the aim of stimulate economic growth in poor regions. But talking about regional policy in Spain is, above all, talking about the financing of regional public investment; and vice versa.

The Spanish and European regional policies are designed in a complementary way and oriented towards the poorest regions. The main financial instruments are the European Structural Funds (ESF) and the Fondo de Compensación Interterritorial (FCI) founded by the central government. The federal spending power (Watts, 1999) in Spain is reflected in other categories of capital grants to subcentral governments like the Convenios de Inversión (CI) accorded between both tiers in a discretionary and bilateral way.

For instance, between 1990 and 1996, ACs received, in 1990 constant pesetas, 755 billions by means of the FCI, 1791 billions by ESF and 441 billions and (CI) ${ }^{4}$. The statistical correlation between total conditional grants received in per capita terms and 1996 regional GDP per capita is -0.47 . Correlations of each one of the sources of revenues with GDP are -0.90 (FCI), -0.45 (ESF) and -0.20 (CI) ${ }^{5}$. The redistributive bias is very high in the case of FCI, moderate in the case of ESF and quite low for CI.

\footnotetext{
${ }^{2}$ There are 17 Regional Governments corresponding to the same number of Comunidades Autónomas (Autonomous Comunities or ACs). Suárez-Pandiello (1999) and Castells (2000) offer good surveys on Spanish fiscal federalism.

3 See Correa and Manzanedo (2002) for a comprehensive analysis of regional policy in Spain during the period 1983-1999.

${ }^{4}$ Source of data: Analistas Financieros Internacionales (http://www.sectorpublico.com). While resources from FCI and CI must be devoted to capital spending, a -minor- part of ESF covers current expenditures.

${ }^{5}$ All figures have been deflated using the Spanish GDP deflator and divided by the regional population in 1996. The statistical source for both variables is the INE (http://www.ine.es).
} 
Fiscal federalism in Spain shows several features very important for the analysis of fungibility of capital grants:

i) While the devolution of spending powers to the ACs has taken place since 1978 in a short period of time, the many asymmetries in the Spanish fiscal federalism must be outlined in order to grasp its complexity. The first and most important of them concerns the existence of two clear-cut sorts of ACs. On the one hand, Navarra and País Vasco enjoy the Foral Regime. The rest of ACs is regulated by what is known as the Common Regime. Due to historical reasons, the former enjoy a radically different system of financing, which means a much higher degree of autonomy and a higher level of resources per capita with similar tax rates because of their low contribution to national equalization ${ }^{6}$. Regional government of Navarra and provincial governments in País Vasco ${ }^{7}$ collect almost all the taxes in their territories and transfer an amount to the Central Government yearly. Both ACs can modify the structure of their fiscal system -except in the indirect taxes- subject to the harmonization rules imposed by the European Union and the Spanish State. In the case of ACs under the second regime, the bulk of their spending has been financed by means of conditional and unconditional grants from the central government ${ }^{8}$.

ii) According to the dynamics of the devolution process, one may divide the ACs into two main groups, despite the existence of second-order disparities among the members of each one. On the one hand, there exist the Foral ACs and a set of five Common ACs comprising Cataluña, Galicia, Andalucía, Canarias and Comunidad Valenciana. The members of the second group are Asturias, Cantabria, Madrid, La Rioja, Baleares, Murcia, Extremadura, Castilla y Leon, Castilla-La Mancha and Aragón. Central Government has been faster

\footnotetext{
${ }^{6}$ Navarra and País Vasco amount to around 7\% of total Spanish population and $8 \%$ of Spanish GDP. Their contribution to finance public services in the poor regions is neatly lower than the corresponding to regions with similar per capita GDP but under the Common Regime, as Cataluña.

${ }^{7}$ The three provincial governments in Pais Vasco collect the taxes and transfer the lion's share the regional government, because the later detain the most important spending powers.

${ }^{8}$ In 2002 the system has been deeply modified to lessen vertical fiscal imbalances, but it is irrelevant for the sample used in this paper.
} 
devolving powers to the former group. Since the cession of health services to the other group in 2002, and setting aside some regional particularities ${ }^{9}$, a high homogeneity of powers has been attained.

iii) The third asymmetry is reflected into the wide vertical imbalance suffered by the common ACs. The strong devolution of spending powers has not been accompanied by a decentralization of the tax system. The financial dependence from the State seems to have no parallels across the world. More than 70 per cent of common ACs public spending in 1999 was financed by means of grants ${ }^{10}$. Public debt has been the real source of autonomy for regional government before then.

\section{THE MODEL AND DATA}

Owing to the asymmetries mentioned above, the models usually used in the empirical work are not very illuminating for the Spanish common $\mathrm{ACs}^{11}$. The level and dynamics of current expenditures in each region have depended, by and large, on the rhythm of devolution of powers and the rules governing grants, and not on per capita disposable income or proxy variables of preferences on public goods (Lago-Peñas, 2001b).

On the revenue side, resources from own taxes have been residual in common ACs, because of legal and political constraints. ACs cannot tax fiscal bases previously taxed by central and local governments. Besides, the political costs attached to additional charges imposed by a new level of government in a context where the rest of regions opts for debt or for pressing the central level to get more grants could be significant. Hence, the

\footnotetext{
${ }^{9}$ For instance, some ACs have their own police or they develop a linguistic policy to encourage the use of their own languages or, in the case of ACs composed by just one province, the former has assumed the powers of the later. See Castells (2000).

${ }^{10}$ For the whole period 1984-1996, the percentage rises until 85 per cent if one takes into account the collection of central taxes ceded to regions without normative powers until 1997.

${ }^{11}$ As García-Milá and McGuire (1990) posit: "Because the level of ACs expenditures differs very little from the level of grants to the ACs, estimation of a traditional local government demand equation, in which expenditures per capita are regressed on a set of variables describing tastes and resources of the jurisdictions, with grants being a key variable, makes little sense in the Spanish context" (García-Milá and McGuire, 1990).
} 
evolution of saving has basically depended on the dynamics of current grants and current expenditures.

For all these reasons, foral ACs have been excluded and an approach analogous to that proposed by Pack and Rothenberg (1990 and 1993), outlining the trade-offs in the composition of spending and revenues, is followed.

Regional governments aiming the maximization of social welfare should solve the following problem

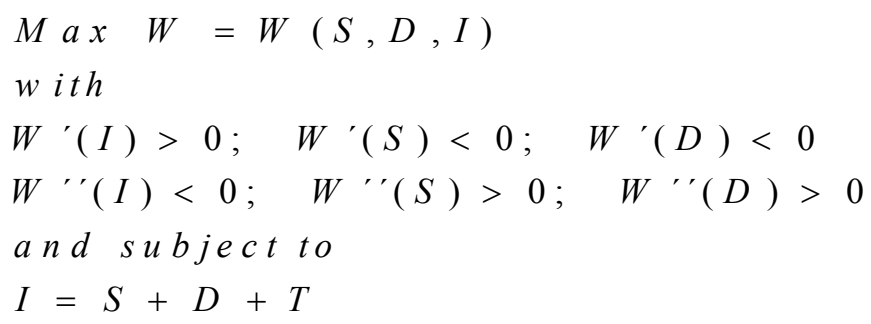

where $\mathrm{W}$ is social welfare; $\mathrm{I}$ is investment; $\mathrm{T}$ are capital grants; $\mathrm{D}$ is deficit; and $\mathrm{S}$ is saving.

Regional governments bear another constraint. Their investment must exceed the level of capital inflow and required counterpart expenditures attached to grants included in ESF and CI programs

$$
\begin{aligned}
& I \geq(1+m) \cdot T \\
& \text { with } \\
& m=\sum_{i=1}^{n} m_{i} \cdot \frac{T_{i}}{T} ; \quad T=\sum_{i=1}^{n} T_{i} ; \quad m_{i} \geq 0
\end{aligned}
$$

where $m_{i} \cdot T_{i}$ is the counterpart required to the AC corresponding to the $\mathrm{i}$-th capital transfer $\left(\mathrm{T}_{\mathrm{i}}\right)$. Anyway, as in Heller (1975), this proves to be a nonbinding constraint for the present sample. It would be probably more relevant to understand the value of T since ACs could refuse transfers if the level of required self-financed investment were too high ${ }^{12}$.

\footnotetext{
${ }^{12}$ In this sense, capital transfers would not be completely exogenous. Moreover, as Knight (2002) points out, grants should be treated as an endogenous variable because of the politics behind their distribution among
} 
Regional governments aiming welfare maximization will fix investment, saving and deficit to balance their marginal effects on welfare in absolute value: $W^{\prime}(I)=\left|W^{\prime}(D)\right|=\left|W^{\prime}(S)\right|$ and meet their budget constraints. Because saving is the difference between current grants $(\mathrm{G})$, own taxes (TA), and current expenditures (C): $S=G+T A-C$, governments will choose the optimal composition of saving to get: $W^{\prime}(C)=\left|W^{\prime}(T A)\right|=\left|W^{\prime}(S)\right|$. According to this model of fiscal choices and data, relative cost of TA in terms of social welfare would have been extremely burdensome for the ACs in the past.

Variations in the volume of capital grants alter optimal values for endogenous variables. What is the effect of an increase in transfers? It should rise capital spending because it must be legally used to finance it and because of financial participation of ACs in plans. Nevertheless, an increase in resources should be distributed among different uses to hold welfare maximization conditions. If self-financed capital spending before the rise in grants is higher than obligatory regional participation in projects financing $\left(S+D>m \cdot T+m_{n+1} \cdot T_{n+1}\right)$, additional grants could be used de facto to reduce saving and deficit.

Let us suppose that regional governments take lagged values of fiscal variables as initial references for their optimal choices ${ }^{13}$, adapting them to individual and common innovations. Capital grants must be included in the first category. Additional variables to proxy individual innovations have been considered. The more powers are devolved and global resources are disposable, the more capacity and need there is to allocate money to capital spending (Lago-Peñas, 2001a). Hence, the incorporation of public consumption $(C)$ and a dummy variable (POW), adopting value 1 for ACs enjoying a higher level of powers from the early stages of the decentralization process and 0 for the rest, has been explored. exogeneity of T should be tested. 
In the case of $\mathrm{D}$, the debt stock, proxied by the ratio $E=\frac{\text { debt stock }}{\text { total current resources }}$, could affect the cost of additional debt. When the ratio grows, interest rates would tend to rise (Stiglitz and Weiss, 1981), and the worry of voters about future taxes and debt sustainability would increase (Hamilton and Flavin, 1986).

The effects of reforms in the Spanish intergovernmental fiscal relations, the incidence of limits to regional deficits, progressively stronger in Spain since 1992 (Vallés, 2002), and the consequences of Spanish economic cycles and long-run growth on regional public revenues and expenditures would be examples of common innovations. Temporal fixed effects are included in regressions to control for them.

Therefore, equations to estimate are the following

$$
\begin{aligned}
& I_{i t}=\alpha_{i}+\rho_{i} \cdot I_{t-1}+\beta_{i} T_{i t}+\sum_{t=2}^{T-1} \delta_{t} \cdot X_{t}+\sum_{k=1}^{j} \gamma_{i k} \cdot Z_{i t}+\varepsilon_{i t} \\
& S_{i t}=\alpha_{i}+\rho_{i} \cdot S_{t-1}+\beta_{i} T_{i t}+\sum_{t=2}^{T-1} \delta_{t} \cdot X_{t}+\sum_{k=1}^{j} \gamma_{i k} \cdot Z_{i t}+\varepsilon_{i t} \\
& D_{i t}=\alpha_{i}+\rho_{i} \cdot D_{t-1}+\beta_{i} T_{i t}+\sum_{t=2}^{T-1} \delta_{t} \cdot X_{t}+\sum_{k=1}^{j} \gamma_{i k} \cdot Z_{i t}+\varepsilon_{i t}
\end{aligned}
$$

where $X_{i}$ are a set of dummies adopting value 1 for observations in year $t$ and 0 for the rest, and $Z_{i}$ are other control variables.

For reduction of panel heterogeneity and comparability of figures across ACs and time, all data are expressed in pesetas, on per capita basis, and in real terms by deflating the current values using the national public consumption deflator. Data for public consumption, saving, deficit, capital spending and capital grants were derived from the Spanish Ministerio de Economía y Hacienda (MEH, several years, www.meh.es) and data for debt from the Banco de España (BDE, several years, www.bde.es). Capital spending comprises net direct spending and capital grants to other agents. Regional populations and price

\footnotetext{
${ }^{13}$ As in Heller (1975) and Otim (1996).
} 
deflator were taken from the Instituto Nacional de Estadística (INE, www.ine.es). Data were obtainable for 1984-1999.

\section{EMPIRICAL FINDINGS}

The evolution of time period specific means and standard deviations are showed in figure 1 and table 2, and the respective correlation matrix in table 3 . Relative weights of $\mathrm{T}$ and $\mathrm{S}$ in investment financing are similar, with $\mathrm{S}$ increasing in importance along the time. The dispersion of both variables among regions is also similar. Deficit follows a different path. It increases until 1991 and drops afterwards. At the same time, individual deviations from the regional mean are much wider and variable. As it is revealed in table 2, the evolution of $\mathrm{D}$ is not significantly correlated with $\mathrm{T}$ and $\mathrm{S}$. And the moderate correlation between I and D is explained by what happened in 1988-1993, when S and T stagnate and the growth in I was financed almost exclusively by debt.

Simple correlations among cross-section specific means are displayed in table 3 . It deserves to emphasize four data:

(i) the high correlation between $\mathrm{T}$ and I $(+0.84)$

(ii) the moderate and negative correlation between S and D (-0.64)

(iii) the low correlation between $\mathrm{T}$ and $\mathrm{D}(-0.26)$

(iv) the dynamics of $\mathrm{T}$ and $\mathrm{S}$ are not directly connected $(+0.07)$

Table 4 depicts estimations of equation (1) to (3) using cross-section specific means. Both standard OLS t-statistics and white t-statistics robust to heteroscedasticity are reported below coefficients. Results from estimations without POW as regressor were expected and coherent with simple correlations contained in table 3. But things change once POW is included in regressions. When institutional differences among ACs are taken into account, a negative relation is found between $\mathrm{T}$ and $\mathrm{D}$ and a positive but scarcely significant relation between $\mathrm{S}$ and $\mathrm{T}$. 
Grants would have been mostly but not completely used for finance capital spending. In average, each euro granted to ACs to finance capital spending raises $\mathrm{G}$ by 0.9 and drops $\mathrm{D}$ in 0.2 . However, these estimations discard time series information. Do results hold when it is used?

The first step to estimate the Data Generator Process (DGP) of all variables is to elucidate the presence of unit roots and/or trend stationary processes. The short span of temporal series recommends the use of panel data methodology (Baltagi and Kao, 2000). Because the power of unit root tests depends on the choice of an appropriate specification, some homogeneity tests on a general equation have been applied to select a plausible description of the data under both the null and the alternative hypothesis. As stated by table 5 , it would be reasonable to accept the hypothesis of total homogeneity in the case of variables I, C, D, and E. On the contrary, individual effects should be included in the case of S, and individual fixed effects, slopes and time trends for $\mathrm{T}$.

The results of ADF tests designed by Levin and Lin (1992) and Im, Pesaran and Shin (see Chiang and Kao, 2000) are summarised in table 6. Variable E would be integrated of order 1 or I(1) and the rest would be I(0).

The OLS estimation of equation (1) yields the results reported in the first column of table 7. Homogeneity tests on constants and slopes could be accepted. The fitness of the equation is good. The Hausman test on exogeneity of variable $\mathrm{T}$ and the Breusch-Godfrey test on residual autocorrelation do not reveal problems in both senses. Nevertheless, a LM test applied on the OLS residuals ${ }^{14}$ detected cross-section heteroscedasticity, and the

${ }^{14} L M=\frac{T}{2} \sum_{i=1}^{n}\left[\frac{s_{i}^{2}}{s^{2}}-1\right]^{2}$ where $\mathrm{s}^{2}$ are estimated variances using OLS residuals, $\mathrm{n}$ is the number of individuals and T the number of periods. See Greene (1997). 
carrying out of another LM test ${ }^{15}$ pointed out the presence of contemporaneous correlations.

The variance estimator proposed by White (1980) is robust to heteroscedasticity within each cross-section, but does not account for contemporaneous cross-section correlations. And there are a number of potential pitfalls associated with the application of SUR weighted least squares (sometimes referred to as the Parks estimator) with a small number of time periods as in this case (Beck et al, 1993; Beck and Katz, 1995). For this reason, they propose to retain OLS parameter estimates, replacing the OLS standard errors with panel-corrected standard errors. The new "robust" covariance matrix is

$\operatorname{Var}(\hat{\beta})=\left(\sum_{i=1}^{n} X_{i}^{\prime} X_{i}\right)^{-1}\left(\sum_{i=1}^{n} \sum_{j=1}^{n} \sigma_{i j} X_{i}^{\prime} X_{j}\right)\left(\sum_{i=1}^{n} X_{i}^{\prime} X_{i}\right)^{-1}$

where covariances $\sigma_{\mathrm{ij}}$ are estimated using OLS residuals.

More recently, Greene (1997) have suggested the use of FGLS to correct by crosssection heteroscedasticity in parameter estimates, replacing the estimated covariance matrix with

$\operatorname{Var}(\hat{\beta})=\left[\sum_{i=1}^{n}\left(\frac{1}{s_{i i}}\right) X_{i}^{\prime} X_{i}\right]^{-1}\left[\sum_{i=1}^{n} \sum_{j=1}^{n}\left(\frac{r_{i j}^{2}}{s_{i j}}\right) X_{i}^{\prime} X_{j}\right]\left[\sum_{i=1}^{n}\left(\frac{1}{s_{i i}}\right) X_{i}^{\prime} X_{i}\right]^{-1}$

where $r_{i j}$ are the correlation coefficients and $s_{i i}$ and $s_{i j}$ are the covariances derived from the FGLS residuals.

Under each estimated coefficient in table 6 appear, in parenthesis, the t-statistic computed using the standard OLS covariance matrix or the FGLS covariance matrix and, in brackets, the t-statistics derived from equations (4) and (5), respectively. Basic results do

${ }^{15} \lambda_{L M}=T \sum_{i=2}^{n} \sum_{j=1}^{i-1} r_{i j}^{2}$ where $r_{i j}^{2}$ are squared correlations among FGLS residuals. See Breusch and Pagan (1980). 
not change substantially with the estimation method (OLS in column 1 and FGLS in column 2) or the variance matrix estimator used.

As it is known, F-statistics are valid only if it is possible to assume that the errors are independent and identically normally distributed. As an alternative, Wald appropriated tests were implemented. Results appear below the corresponding to the F-statistics of homogeneity. Previous conclusions in this respect may be hold.

Estimations reflect that short-run multiplier of $\mathrm{T}$ on $\mathrm{I}$ is 0.4 but long-run multiplier $\left(\frac{\beta}{1-\rho}\right)$ is not statistically different to one ${ }^{16}$.

While previous comments about the specification of the econometric model are basically the same for estimations of equation (3) displayed in columns 7 to 10, they differ for estimations of equation (2) shown in columns 3 to 6 . The hypothesis of homogeneity of individual effects is rejected according to the corresponding tests. Moreover, the serial autocorrelation of residuals, marked by the significant value of the Breusch-Godfrey statistic, reinforces the need of dealing with the heterogeneity of the panel. With this aim, fixed individual effects are included. This solution removes both problems.

Unfortunately, as it is well known, using the standard within-group estimator for dynamic models with fixed individual effects generates inconsistent estimates. Nickell (1981) shows that when $\rho$ is positive, the bias on $\hat{\rho}$ is negative. The inclusion of exogenous variables makes the bias larger in absolute value. The bias on $\hat{\beta}$ depends on the

\footnotetext{
${ }^{16}$ The following t-statistic was computed deriving variances and covariances from equations (4) and (5) $t=\frac{\hat{\beta}+\hat{\rho}-1}{\sqrt{\operatorname{var}(\hat{\beta})+\operatorname{var}(\hat{\rho})+2 \operatorname{cov}(\hat{\beta}, \hat{\rho})}}$.
} 
sign of the relationship between the exogenous variable and the lagged endogenous. When they are positively related, the coefficient will be upward biased and vice-versa ${ }^{17}$.

What are the implications of these results for estimations of equation (2) including individual fixed effects? On the one hand, $\hat{\rho}$ is downward biased because $\rho>0$. On the other, supposing $\beta<0, \hat{\beta}$ would be downward biased and then $\beta>\hat{\beta}$. Combining this result with the low value of $\hat{\beta}$ in both equations and its low statistical significance, one must conclude that $\mathrm{T}$ has no a significant effect on $\mathrm{S}^{18}$.

Some comments about the set of control variables. Temporal fixed effects are highly significant in general, but not $\mathrm{C}$. Moreover, bear in mind that variable $\mathrm{C}$ is $\mathrm{I}(1)$ and variable $\mathrm{I}$ behaves as an $\mathrm{I}(0)$ process. Variable $\mathrm{E}$ was excluded from deficit regressions because of multicollinearity problems. The coefficient of determination for the regression of $\mathrm{E}$ on the other regressors was around 0.6 ; which is higher than the overall $\mathrm{R}^{2}$.

Dummy variable POW is highly significant in deficit regressions. Its inclusion reinforces the relevance of $\mathrm{T}$ in such a way that it becomes not possible to reject its statistical significance at usual levels. Transfers would have contributed to cut deficit.

Summarising, capital grants are not relevant to explain the dynamics of S but they are significant in deficit regressions when variable POW is included. Each additional euro granted to ACs lessens deficit around 0.1 euro in the short-run. Anyway, while the shortrun multiplier of $\mathrm{T}$ on $\mathrm{I}$ is around 0.4 long-run multiplier would not be different to 1 . Therefore it would be possible to discard crowding-out or crowding-in effects in the long

\footnotetext{
${ }^{17}$ According to Nickell (1981), the bias is given by

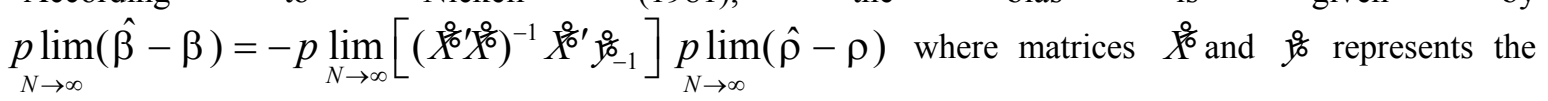
mean differenced $X$ and $y$.

${ }^{18}$ If $\beta>0$ then $\hat{\beta}>\beta$ due to the direction of the bias. But estimations show that $\hat{\beta} \leq 0$.
} 
run. All results were basically the same when the sample was split into two intervals: 19841991 and 1992-1999.

\section{CONCLUSIONS}

Capital grants are implemented to increase and promote investments carried on by recipients. Conditions on the use of financial aid are imposed to avoid the employment of additional resources to cut taxes, reduce deficit, or increase public consumption. In spite of it, governments may try to obviate legal constraints by altering their self-financed investment.

Using data for Spanish ACs during the period 1984-1999, I have found that the dynamics of saving has not been systematically affected by the evolution of capital grants. On the contrary, increases in capital transfers have involved a lower deficit.

Anyway, the existence of a crowding-out effect in the long-run is rejected by data. In general, ACs do not respond automatically to ups and downs in the volume of capital grants modifying their investments in the same amount. ACs seem to soften the effects of grants on fiscal variables but they do not substitute self-financed investment by grants in the long- run. According to the results presented above, capital grants programmes would have been successful in promoting the accumulation of public capital stock by ACs.

\section{REFERENCES}

-Baltagi. B. and Kao, C. (2000): "Nonstationary Panels, Cointegration in Panels and Dynamic Panels: A Survey", mimeo.

-Beck, N; Katz, J.N.; Alvarez, M; Garrett, G. and Lange, P. (1993): "Government Partisanship, Labor Organization, and Macroeconomic Performance: A Corrigendum", American Political Science Review, 87, 945-948. 
-Beck, N, and Katz, J.N. (1995): "What To Do (and not To Do) with Time-Series CrossSection Data", American Political Science Review, 89, 634-647.

-Banco de España [BDE] (several years): Boletín Estadístico, (Banco de España, Madrid).

-Breusch, T and Pagan, A. (1980): "The LM Test and Its Applications to Model Specification in Econometrics", Review of Economics Studies, 47, 239-254

-Castells, A. (2000): “The Role of Intergovernmental Finance in Achieving Diversity and Cohesion: The Case of Spain", Documents de Treball, Institut d'Economia de Barcelona, 2000-2 (http://www.pcb.ub.es/ieb/serie/serie.html).

-Chernick, H. (1998): "Fiscal Effects of Block Grants for the Needy: An Interpretation of the Evidence", International Tax and Public Finance, 5, 205-233.

-Chiang, M. and Kao, C. (2000): "Nonstationary Panel Time Series Using NPT 1.1 - A User Guide", (Center for Policy Research, Syracuse University).

-Correa, M.D. and Manzanedo, J. (2002): "Política regional española y europea. Período 1983-1999”, Documentos de Trabajo, SGFCC-2002-05, Dirección General de Presupuestos, (Ministerio de Hacienda, Madrid).

-Gamkhar, S. (2002): Federal Intergovernmental Grants and the States, (Edward Elgar, Cheltenham).

-Gang, J. N. and Khan, H. A. (1991): "Foreign Aid, Taxes, and Public Investment", Journal of Development Economics, 34, 355-369.

-García-Milá, T. and McGuire, T.J. (1990): "The Effects of Central Government Financing on Regional Government Expenditures in Spain", in Prud'homme, R. (Ed.): Public Finance with Several Levels of Government, Proceedings of the 46th Congress of the International Institute of Public Finance, (IIPF Brussels).

-Greene, W.H. (1997): Econometric Analysis (Third Edition), (Prentice Hall, New Jersey).

-Grossman, P.J. (1989): “Intergovernmental Grants and Grantor Government Own-Purpose Expenditures", National Tax Journal, 42, 487-494.

-Hamilton, J.D. and Flavin, M.A. (1986): “On the Limitations of Government Borrowing: A Framework For Empirical Testing", American Economic Reviewm Vol.76 (4), pp.808819. 
-Heller, P.S. (1975): “A Model of Public Fiscal Behaviour in Developing Countries: Aid, Investment and Taxation", American Economic Review, 65, 429-445.

-Islam, M. and Choudhury, S.A. (1990): "testing the Exogeneity of Grants to Local Governments", Canadian Journal of Economics, 23, 676-692.

-Khan, H. A. and Hoshimo, E. (1992): "Impact of Foreign Aid on the Fiscal Behaviour of LDC Countries", World Development Economics, 20, 1481-1488.

-King, D.N. (1984): Fiscal Tiers: The Economics of Multilevel Governments, (George Allen \& Unwin, London).

-Knight, B. (2002): "Endogenous Federal Grants and Crowd-out of State Government Spending: Theory and Evidence from the Federal Highway Aid Program", American Economic Review, 92, 71-92.

-Lago-Peñas, S. (2001a): "La dinámica de los gastos de capital de las Comunidades Autónomas: Un análisis de sus determinantes”, Hacienda Pública Española,157, 65-82.

-Lago-Peñas, S. (2001b): "La evolución del gasto público autonómico y el sistema de financiación de las Comunidades de régimen común”, Estudios sobre la Economía Española, EEE101, FEDEA, (http://www.fedea.es).

-Levin, A. y Lin, C.H. (1992): "Unit Root Tests in Panel Data: Asymptotic and Finite Sample Properties”, Discussion Papers, 92-93 (University of California, San Diego).

-Meyers, H.G. (1987): “Displacement Effects of Federal Highway Grants”, National Tax Journal, 40, 221-235.

-Ministerio de Economía y Hacienda [MEH] (several years): Liquidación de presupuestos de las Comunidades Autónomas, (Ministerio de Economía y Hacienda, Madrid).

-Nickell, S. (1981): "Biases in Dynamic Models with Fixed Effects", Econometrica, 49, 1417-1426.

-Oates, W.E. (1972): Fiscal Federalism, (Harcourt Brace Jovanovich, New York).

-Otim, S. (1996): "Foreign Aid and Government Fiscal Behaviour in Low-Income South Asian Countries", Applied Economics, 28, 927-933.

-Pack, H. and Rothenberg, J. (1990): "Is Foreign Aid Fungible? The Case of Indonesia", Economic Journal, 100, 188-194. 
-Pack, H. and Rothenberg, J. (1993): "Foreign Aid and the Question of Fungibility", The Review of Economics and Statistics, 75, 258-265.

-Stiglitz, J. and Weiss, A. (1981): "Credit rationing in Markets with Imperfect Information", American Economic Review, 71, 393-410.

-Suárez-Pandiello, J. (1999): "Fiscal Federalism in Spain. Decentralization: An Unfinished Task" in Fossati, A. and Panella, G. (Eds.): Fiscal Federalism in the European Union, (Routledge, London).

-Vallés, J. (2002): “La coordinación de las políticas de endeudamiento autonómico: una aproximación a los factores explicativos de los Escenarios de Consolidación Presupuestaria”, Estudios sobre la Economía Española, EEE125, (http://www.fedea.es)

-Watts, R.L. (1999): The Spending Power in Federal Systems: A Comparative Study,: (Institute of Intergovernmental Relations, Kingston).

-White, H. (1980): A Heteroskedastic-Consistent Covariance Matrix Estimator and a Direct Test for Heteroskedasticity", Econometrica, 48, 817-838.

-Wildasin, D.E. (1986): Urban Public Finance, Harwood Academic Publishers, Switzerland).

-Zampelli, E.M. (1986): "Resource Fungibility, the Flypaper Effect, and the Expenditure Impact of Grants-in-Aid", The Review of Economics and Statistics, 68, 33-40.

-Zou, H.F. (1994): “Dynamic Effects of Federal Grants on Local Spending”, Journal of Urban Economics, 36, 98-115. 
Figure 1: Time period specific means of variables (1984-99)

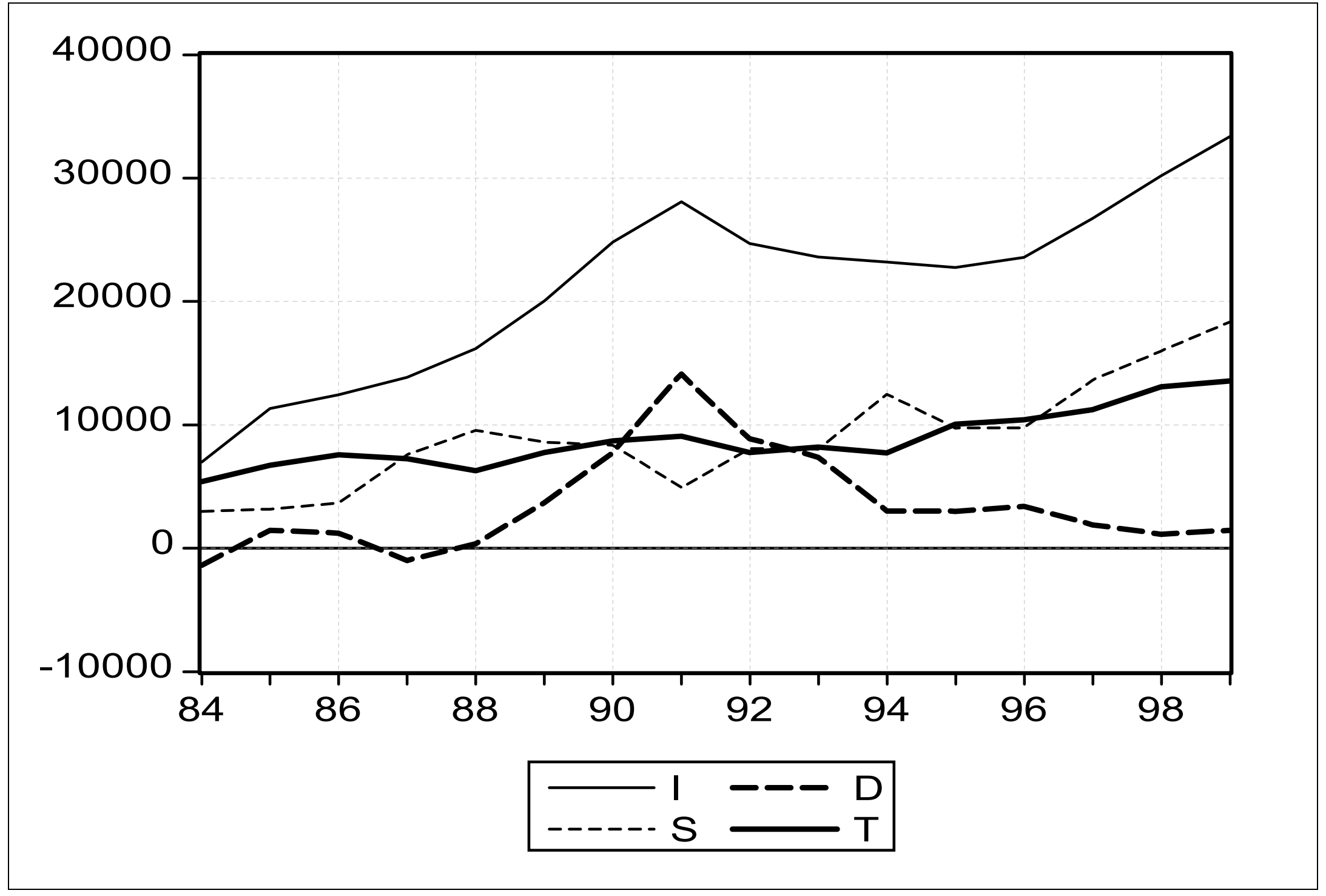


Table 1: Time period specific means and standard deviations of variables

\begin{tabular}{||c|c|c|c|c|c|c|c|c||}
\hline & MEAN I & SD I & MEAN T & SD T & MEAN S & SD S & MEAN D & SD D \\
\hline 1984 & 6990 & 2414 & 5401 & 3447 & 2980 & 2583 & -1391 & 2811 \\
\hline 1985 & 11327 & 3256 & 6713 & 2499 & 3161 & 2551 & 1453 & 4157 \\
\hline 1986 & 12448 & 3120 & 7587 & 3247 & 3652 & 2458 & 1209 & 4538 \\
\hline 1987 & 13839 & 4541 & 7263 & 4717 & 7581 & 4485 & -1004 & 5896 \\
\hline 1988 & 16178 & 4728 & 6269 & 2600 & 9559 & 3733 & 350 & 2964 \\
\hline 1989 & 20033 & 5810 & 7759 & 4390 & 8573 & 4571 & 3701 & 5812 \\
\hline 1990 & 24800 & 6602 & 8706 & 6176 & 8350 & 3613 & 7744 & 8007 \\
\hline 1991 & 28077 & 6931 & 9071 & 4456 & 4891 & 4554 & 14115 & 5856 \\
\hline 1992 & 24703 & 9258 & 7761 & 4561 & 8079 & 4125 & 8863 & 5541 \\
\hline 1993 & 23596 & 7584 & 8206 & 4545 & 8012 & 3964 & 7378 & 5314 \\
\hline 1994 & 23193 & 7600 & 7720 & 5157 & 12465 & 7568 & 3008 & 11401 \\
\hline 1995 & 22737 & 9078 & 10039 & 7294 & 9733 & 4991 & 2965 & 4818 \\
\hline 1996 & 23561 & 6187 & 10414 & 5747 & 9747 & 6253 & 3401 & 5516 \\
\hline 1997 & 26732 & 6779 & 11229 & 6019 & 13601 & 5078 & 1902 & 3243 \\
\hline 1998 & 30161 & 7826 & 13078 & 6643 & 15962 & 5510 & 1122 & 3925 \\
\hline 1999 & 33341 & 9122 & 13569 & 6215 & 18317 & 6804 & 1455 & 5237 \\
\hline
\end{tabular}

Table 2: Correlation matrix (Time period specific means)

\begin{tabular}{||c|c|c|c|c||}
\hline & $\mathrm{I}$ & $\mathrm{S}$ & $\mathrm{D}$ & $\mathrm{T}$ \\
\hline $\mathrm{I}$ & 1 & & & \\
\hline $\mathrm{S}$ & 0.77 & 1 & & \\
\hline $\mathrm{D}$ & 0.48 & -0.16 & 1 & \\
\hline $\mathrm{T}$ & 0.84 & 0.81 & 0.06 & 1 \\
\hline
\end{tabular}

Table 3: Correlation matrix (Cross-section specific means)

\begin{tabular}{||c|c|c|c|c||}
\hline & $\mathrm{I}$ & $\mathrm{S}$ & $\mathrm{D}$ & $\mathrm{T}$ \\
\hline $\mathrm{I}$ & 1 & & & \\
\hline $\mathrm{S}$ & 0.45 & 1 & & \\
\hline $\mathrm{D}$ & -0.19 & -0.63 & 1 & \\
\hline $\mathrm{T}$ & 0.84 & 0.07 & -0.26 & 1 \\
\hline
\end{tabular}


Table 4: Regressions with cross-section specific means data $\left(\bar{I}_{i}=\alpha+\beta \bar{T}_{i}+\gamma P O W_{i}+\bar{\varepsilon}_{i}\right)$

\begin{tabular}{|c|c|c|c|c|c|c||}
\hline $\begin{array}{c}\text { DEPENDENT } \\
\text { VARIABLE }\end{array}$ & $\mathrm{I}$ & $\mathrm{I}$ & $\mathrm{S}$ & $\mathrm{S}$ & $\mathrm{D}$ & $\mathrm{D}$ \\
\hline Constant & 13044 & 13356 & 8958 & 9109 & 4757 & 3934 \\
& $(8.41)$ & $(8.41)$ & $(4.20)$ & $(4.53)$ & $(3.58)$ & $(5.54)$ \\
& {$[7.26]$} & {$[8.16]$} & {$[4.02]$} & {$[4.16]$} & {$[3.58]$} & {$[7.38]$} \\
\hline $\mathrm{T}$ & 0.91 & 0.89 & 0.05 & 0.09 & -0.14 & -0.20 \\
& $(5.58)$ & $(5.42)$ & $(0.24)$ & $(0.43)$ & $(-0.99)$ & $(-2.78)$ \\
& {$[5.74]$} & {$[6.56]$} & {$[0.30]$} & {$[0.53]$} & {$[-1.08]$} & {$[-4.37]$} \\
\hline POW & & 1527 & & -2508 & & 4035 \\
& $(1.04)$ & & $(-1.38)$ & & $(6.27)$ \\
& & {$[1.15]$} & & {$[-1.39]$} & & {$[5.34]$} \\
\hline $\begin{array}{c}\text { W } \\
(p-v a l u e s)\end{array}$ & 0.83 & 0.14 & 0.08 & 0.26 & 0.57 & 0.94 \\
\hline R & 0.70 & 0.73 & 0.00 & 0.14 & 0.07 & 0.78 \\
\hline $\begin{array}{c}\text { Number of } \\
\text { observations }\end{array}$ & 15 & 15 & 15 & 15 & 15 & 15 \\
\hline
\end{tabular}

Notes: Below each coefficient appears, in parenthesis, standard t-statistics and, in brackets, White t-statistics robust to heterocedasticity. W is the statistic corresponding to the White test on the null hypothesis of homocedasticity. $\mathrm{R}^{2}$ is the coefficient of determination.

Table 5: Homogeneity tests on specification: $\Delta y_{i t}=\alpha_{i}+\beta_{i} \cdot y_{i t-1}+\gamma_{i} \cdot t+\varepsilon_{i t}$. Estimation Method: OLS

\begin{tabular}{||c|c|c|c|c||}
\hline \hline TEST & $\mathrm{F}(1)\left(\mathrm{F}_{14,208}\right)$ & $\mathrm{F}(2)\left(\mathrm{F}_{14,194}\right)$ & $\mathrm{F}(3)\left(\mathrm{F}_{14,180}\right)$ & $\mathrm{F}(4)\left(\mathrm{F}_{42,180}\right)$ \\
\hline $\mathrm{I}$ & 1.73 & 0.83 & 0.07 & 0.84 \\
\hline $\mathrm{T}$ & $4.40(*)$ & $2.96\left(^{*}\right)$ & $1.88(* *)$ & $2.45(*)$ \\
\hline $\mathrm{S}$ & $2.85(*)$ & 1.70 & 1.43 & $1.45(* *)$ \\
\hline $\mathrm{D}(* * *)$ & 0.54 & 0.54 & 0.68 & 0.33 \\
\hline $\mathrm{C}$ & 0.93 & 1.30 & 0.82 & 0.70 \\
\hline $\mathrm{E}$ & 0.26 & 0.36 & 1.18 & 0.19 \\
\hline
\end{tabular}

$\mathrm{F}(1)$ : Homogeneity test on intercepts

$\mathrm{F}(2)$ : Homogeneity test on lagged terms.

$\mathrm{F}(3)$ : Homogeneity test on time trends.

F(4): Total Homogeneity test.

$(*)$ indicates rejections of homogeneity at the $1 \%$ level, or $5 \%$ level $(* *)$.

$(* * *)$ Time trend no significant 
Table 6: Panel Unit Root Tests

\begin{tabular}{|c|c|c|c|c|}
\hline TEST & LL(1) & LL(2) & LL(3) & IPS \\
\hline I & ---- & $\mathrm{I}(0)(*)$ & ---- & ---- \\
\hline $\mathrm{T}$ & ---- & ---- & $\mathrm{I}(0)(*)$ & $\mathrm{I}(0)(* *)$ \\
\hline $\mathrm{S}$ & --- & --- & $\mathrm{I}(0)(*)$ & ---- \\
\hline $\mathrm{D}$ & $\mathrm{I}(0)(*)$ & --- & ---- & --- \\
\hline $\mathrm{C}$ & ---- & $\mathrm{I}(1)$ & ---- & --- \\
\hline E & --- & $\mathrm{I}(0)^{*}$ & ---- & ---- \\
\hline
\end{tabular}

LL(1): ADF test suggested by Levin and Lin (1992). With intercept and no time trend. LL(2): ADF test suggested by Levin and Lin (1992). With intercept and time trend.

LL(3): ADF test suggested by Levin and Lin (1992). With fixed effects and individual time trends.

IPS: ADF test suggested by Im, Pesaran, and Shin (1995). With time trend.

$\left.{ }^{*}\right)$ The asterisk indicates rejections of unit root at the $1 \%$ level $(*)$, or $5 \%$ level $(* *)$.

All tests have been implemented using the Gauss program written by Chiang and Kao (2000). 
Table 7: OLS and FGLS estimations of equations (1) to (3)

\begin{tabular}{|c|c|c|c|c|c|c|c|c|c|c|}
\hline DEPENDENT VARIABLE & $\mathrm{I}$ & $\mathrm{I}$ & $\mathrm{S}$ & $\mathrm{S}$ & $\mathrm{S}$ & $\mathrm{S}$ & $\mathrm{D}$ & $\mathrm{D}$ & $\mathrm{D}$ & $\mathrm{D}$ \\
\hline Constant & $\begin{array}{c}8798 \\
(5.44) \\
{[4.80]}\end{array}$ & $\begin{array}{c}6134 \\
(4.83) \\
{[4.68]} \\
\end{array}$ & $\begin{array}{c}6363 \\
(4.69) \\
{[4.82]} \\
\end{array}$ & $\begin{array}{c}6273 \\
(5.83) \\
{[6.19]} \\
\end{array}$ & Fixed Effects & Fixed Effects & $\begin{array}{c}2194 \\
(1.39) \\
{[1.23]}\end{array}$ & $\begin{array}{c}694 \\
(0.59) \\
{[0.55]} \\
\end{array}$ & $\begin{array}{c}1937 \\
(1.25) \\
{[2.13]}\end{array}$ & $\begin{array}{c}826 \\
(0.73) \\
{[1.10]} \\
\end{array}$ \\
\hline $\mathrm{T}$ & $\begin{array}{c}0.39 \\
(5.56) \\
{[4.25]}\end{array}$ & $\begin{array}{c}0.36 \\
(5.71) \\
{[5.40]}\end{array}$ & $\begin{array}{c}0.00 \\
(0.04) \\
{[0.05]}\end{array}$ & $\begin{array}{c}-0.01 \\
(-0.32) \\
{[-0.33]}\end{array}$ & $\begin{array}{c}-0.02 \\
(-0.20) \\
{[-0.29]}\end{array}$ & $\begin{array}{c}-0.05 \\
(-0.79) \\
{[-1.26]} \\
\end{array}$ & $\begin{array}{c}-0.10 \\
(-1.45) \\
{[-1.34]}\end{array}$ & $\begin{array}{c}-0.06 \\
(-1.14) \\
{[-1.20]}\end{array}$ & $\begin{array}{c}-0.13 \\
(-1.95) \\
{[-1.86]}\end{array}$ & $\begin{array}{c}-0.12 \\
(-2.17) \\
{[-2.09]}\end{array}$ \\
\hline $\mathrm{I}(-1)$ & $\begin{array}{c}0.64 \\
(11.60) \\
{[7.43]} \\
\end{array}$ & $\begin{array}{c}0.70 \\
(13.90) \\
{[10.77]} \\
\end{array}$ & & & & & & & & \\
\hline $\mathrm{S}(-1)$ & & & $\begin{array}{c}0.75 \\
(14.30) \\
{[6.25]}\end{array}$ & $\begin{array}{c}0.82 \\
(18.28) \\
{[13.55]}\end{array}$ & $\begin{array}{c}0.45 \\
(6.74) \\
{[6.72]}\end{array}$ & $\begin{array}{c}0.46 \\
(7.29) \\
{[10.71]}\end{array}$ & & & & \\
\hline $\mathrm{D}(-1)$ & & & & & & & $\begin{array}{c}0.52 \\
(8.62) \\
{[4.73]}\end{array}$ & $\begin{array}{c}0.55 \\
(9.36) \\
{[7.68]}\end{array}$ & $\begin{array}{c}0.45 \\
(7.11) \\
{[3.68]}\end{array}$ & $\begin{array}{c}0.44 \\
(7.09) \\
{[5.00]}\end{array}$ \\
\hline POW & & & & & & & & & $\begin{array}{c}2317 \\
(3.10) \\
{[2.71]}\end{array}$ & $\begin{array}{c}2669 \\
(4.42) \\
{[3.87]}\end{array}$ \\
\hline $\mathrm{F}_{\mathrm{ai}=\mathrm{a}}\left(\mathrm{F}_{[14,194]}\right)$ & 1.78 & & 3.34 & & & & 0.97 & & & \\
\hline $\mathrm{F}_{\mathrm{bi}=\mathrm{b}}\left(\mathrm{F}_{[28,166]}\right)$ & 1.62 & & 1.32 & & & & 0.85 & & & \\
\hline $\mathrm{W}_{\mathrm{ai}=\mathrm{a}}\left(\chi^{2}{ }_{14}\right)$ & 25.06 & & 46.38 & & & & 13.72 & & & \\
\hline $\mathrm{W}_{\mathrm{bi}=\mathrm{b}}\left(\chi_{28}^{2}\right)$ & 44.74 & & 37.60 & & & & 23.80 & & & \\
\hline $\mathrm{B}-\mathrm{G}\left(\chi_{1}^{2}\right)$ & 0.08 & & 19.2 & & 0.87 & & 0.01 & & & \\
\hline $\operatorname{LM}\left(\chi_{14}^{2}\right)$ & 85.0 & & 81.6 & & 74.1 & & 129.2 & & & \\
\hline$\lambda_{\mathrm{LM}}\left(\chi_{105}^{2}\right)$ & 155.3 & & 194.6 & & 193.0 & & 140.4 & & & \\
\hline$\beta+\rho-1=0\left(t_{208}\right)$ & 0.42 & 1.52 & & & & & & & & \\
\hline $\mathrm{H}\left(\chi_{1}^{2}\right)$ & 1.94 & 2.07 & & & & & & & & \\
\hline $\mathrm{R}^{2}$ & 0.830 & 0.824 & 0.712 & 0.694 & 0.768 & 0.757 & 0.507 & 0.490 & 0.529 & 0.513 \\
\hline Number of observations & 225 & 225 & 225 & 225 & 225 & 225 & 225 & 225 & 225 & 225 \\
\hline Estimation Method & OLS & FGLS & OLS & FGLS & Within & Within* & OLS & FGLS & OLS & FGLS \\
\hline
\end{tabular}

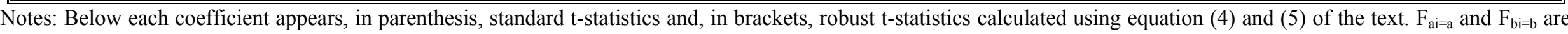

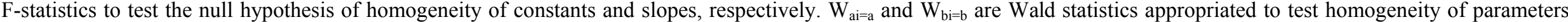

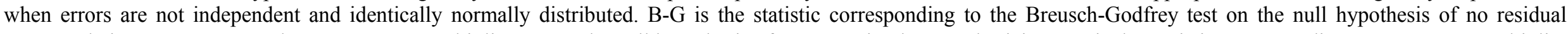

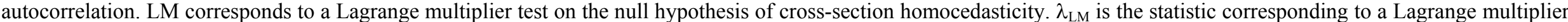

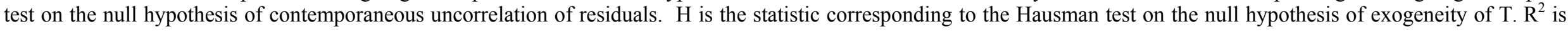

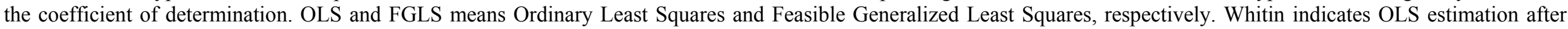
substracting the "within" mean of each variable. Within* indicates FGLS estimation after substracting the "within" mean of each variable. 